\title{
Explaining Change in Communist Successor Parties: Political Environment versus Party Organization?
}

\author{
John Ishiyama
}

The collapse of communism in Eastern Europe and the transformation of the formerly dominant communist parties has provided an opportunity to test some of the major propositions regarding party change. This article focuses on the relationship between external and internal factors, and evolution of the communist successor parties in seventy-nine countries across the world. The most important factor explaining the electoral success of the communist successor parties is the degree of organization, a finding that provides broader support for the literature arguing that communist successor party electoral performance is primarily a result of the organizational features these parties inherited from the past.

\section{Introduction}

The collapse of communism in Eastern Europe and the transformation of the formerly dominant communist parties provides an opportunity to test some of the major propositions regarding party change. In the general literature on political parties there has been a considerable amount of interest in party identity change, or the "face" which the party presents to the electorate (Budge et al. 1987; Janda et al. 1995). By and large, this literature suggests that the principal factors that explain party identity change are external to the party. In other words party change "does not "just happen"" (Harmel and Janda 1994, 261), but results from changes in the political environment or from the electoral failures of the party.

This article focuses on the relationship between external and internal factors, and the evolution of the communist successor parties. The "communist successor" parties are those identified as the organizational descendants of the parties that had been officially recognized by the Soviet Union in 1988 as the principal "communist party." These parties were those that have as "their legacy the former communists" property, membership, political elite or a combination of these, or else are "legal successors" to the communist party (Bozoki 1997, 57; for a more extensive discussion of this definition see Ishiyama 1995).

JOHN ISHIYAMA is Professor of Political Science at Truman State University. His extensive publications include three books and articles in Comparative Politics, Comparative Political Studies, Political Science Quarterly, Political Research Quarterly, Social Science Quarterly, Europe-Asia Studies and Party Politics among many others.

The American Review of Politics, Vol. 23, Winter, 2002: 319-336

(C)2002 The American Review of Politics 
What affects whether these parties changed their identities? Although there have been several recent works that have investigated the development of the communist successor parties, these works have tended to either focus on the extent to which the successor parties have been politically successful (Ishiyama 1997; Orenstein 1998) or how they have adapted organizationally since the collapse of communism as a political system (Ishiyama 1999b; 1995; Mahr and Nagle 1995; Bozoki 1997; Urban and Solovei 1997). Some studies have investigated identity change, but these have been conducted mainly at the level of individual parties or using comparative studies involving a small number of cases (Ziblatt 1998; Grzymala-Busse 1999)

Unlike previous comparative studies of the evolution of the communist successor parties (Ishiyama 1997; Orenstein, 1998), this article seeks to test theories of successor party adaptation in a broader way. I investigate the factors affecting identity change in light of the evidence from a sample of seventy-nine communist successor parties. Several criteria were used to construct the sample of successor parties. First, the parties must have been legal and in existence by the time of the first competitive legislative election after January 1, 1990. Second, there must have been at least one free, open and competitive legislative election between the beginning of 1990 and October 1998. Third, the country's political system must have remained consistently and relatively democratic (meaning a consistent score of four or above on the widely used Freedom House Index) between January 1992 (i.e., following the collapse of the USSR) and October 1998. After taking these criteria into account, data were collected on a sample of 79 individual successor parties. ${ }^{2}$ The list of communist parties and their corresponding successor parties are identified in the Appendix.

Two questions guide this inquiry. First, what explains the degree to which the communist successor parties have changed, particularly in terms of their identity? Second, do changes in the party's identity affect the degree of electoral success a party enjoys following the change in identity? In other words, do parties that changed their identities generally perform better electorally than parties that do not change their identities?

\section{Literature}

\section{Environmental Factors Affecting Party Identity Change}

What causes party identity change? On the one hand, party identity change can be seen as a result of environmental influences. For instance, Janda (1990), Harmel and Janda (1994), and Janda, et al. (1995), have argued that party identity change occurs as the result of parties reacting to changes in the political environment. From this perspective, parties are 
assumed to be conservative organizations that are unlikely to change unless forced (Harmel and Janda 1994). Thus, party change is viewed as a rational and purposeful move by the party in response to specific stimuli.

For Janda one of the most important influences that necessitate party change is extreme competition that results in poor electoral performance (1990). Janda et al. (1995) tested the hypothesis that parties will change only if they do poorly in elections. The authors defined five different kinds of elections as perceived by the party's activists: calamitous, disappointing, tolerable, gratifying and triumphal (Janda et al. 1995). They found that generally calamitous or disappointing elections were associated with the greatest degree of party identity, indicating that parties only try to change their identities when voters reject the policy face they had presented in the previous election.

On the other hand, some scholars have suggested that the greater external challenges a political organization faces, the more likely the followers of that organization will seek to reaffirm its ideological purity (Stewart 1991). As the party faces greater external challenges there is greater pressure to reaffirm the movement's identity, because as Richard Gregg $(1971,74)$ argues there is a need for followers for "psychological refurbishing and affirmation." This usually involves a greater attempt to identify the members of the movement as being different from others. This is a way, as Gregg (1971, 76) notes, to establish selfhood by "identifying against another" establishing one's identity through contrast. Thus the greater the external competition, the more likely the party will seek to maintain its ideological roots (see also Breuning and Ishiyama 1998; Stewart 1991). Kitschelt (1995, 455) suggests that repressive communist regimes were "able to entrench" themselves, and thus effectively preclude the emergence of the challenge of "an independent structure of intellectuals or middle-class professionals." This implies that a communist successor party is successful not because of the party's organizational characteristics, but because its opponents are only weak and disorganized (Kitschelt 1995, 455).

In addition to the performance of rivals, another feature of the structure of competition is the degree to which the party system as a whole is "fragmented" or "fractionalized." The more fractionalized a party system, the more likely that the successor party might be able to win seats in the legislature. This would especially true where electoral thresholds are low (such as in some proportional representation electoral systems).

\section{Organizational Legacies}

Factors internal to the party may also affect the party's ability to change its identity. Epstein (1968) and Panebianco (1988) have noted that different kinds of parties are more likely to adapt then others. From this 
perspective parties that are organized along 'mass' (programmatic) lines tend to be less able to change than are parties that are organized primarily to win election (or what Duverger referred to as 'cadre' parties). This is because mass parties place greater internal constraints placed on leaders in their ability to react to incentives generated by a political environment (Ishiyama and Velten 1998). Indeed, one can imagine the situation where external incentives to moderate a party's political position may have little effect on a party leadership whose range of movement is constrained by the presence of a significant number of 'hardliners' in the ranks of the organization.

Several scholars of party organizations have contended that the organizational features of parties impact their ability to new political circumstances. Much of this work is based on the concept of organizational institutionalization (Huntington 1965). Huntington proposed to measure the level of institutionalization for a particular organization "by its adaptability, complexity, autonomy, and coherence" $(1965,394)$. Although useful, Janda $(1980,19)$ notes that Huntington's approach to measuring the degree of institutionalization fails to recognize party organizations that are clearly institutionalized. For instance he notes "a party can be highly institutionalized but lack the independence of other groups (Huntington's 'autonomy') as the Labour Party in Great Britain." Rather, for Janda an institutionalized party is "one that is reified in the public mind so that 'the party' exists apart from its momentary leaders, and this organization demonstrates recurring patterns of behavior valued by those who identify with it" $(1980,19)$.

\section{Design and Methodology}

\section{Dependent Variables: Party Name Change and Current Position on Marxism-Leninism}

The above literature suggests several variables that will be included in this study. First, turning to the dependent variables, identity change is measured by whether or not the party changed its name after the first election following the collapse of communist systems in Eastern Europe in 1990 and 1991. A change in name would signify the party's attempt at identifying itself with another constituency, and hence is an indicator as to the extent to which the party seeks to accommodate with new political circumstances. The focus here, however, is only on a complete change in the party's name as opposed to only a minor change.

In addition to the name change of the party, a second indicator of change in identity (and hence the willingness to adapt to new political circumstances) is the successor party's attitude vis-à-vis Marxism-Leninism. Each party was coded in terms of whether or not the party had explicitly disavowed Marxism-Leninism in its program between 1990 and 1998, where 
0 was assigned to "had not rejected Marxism-Leninism" and 1 assigned to "had rejected Marxism- Leninism."

\section{Independent Variables: Party Competition}

As mentioned above, the literature suggests that the extent to which parties seek to change their political identities is a function of the degree of competition the party faces. "Competition" was measured in two ways. First, I examine the strength of "left wing competition." Although the strength of left-wing competition has been cited as an important variable affecting the performance of the communist successor parties (Waller 1995; Kopecky 1995; Ishiyama 1995) the concept "left wing," or the entire political spectrum in post-communist politics for that matter, is notoriously difficult to measure. The issue, however, is not to provide indisputable criteria for categorizing a "socialist" from a "non-socialist" party, but to identify those parties which might compete with the communist successor parties for the same constituencies on the ideological spectrum. To address the measurement of the strength of the left wing competition facing the successor parties, two criteria were used. First, a left wing competitor must have won seats in the most recent legislative election. Second, the party must tend to compete for the same constituencies as the communist successor parties. Whether the party competed for the same niche on the ideological spectrum was discerned by identifying the largest parties which won seats and labeled themselves as either communist, socialist or social democratic and determining the average percentage of seats held by the largest leftist competitors in the lower house of parliament from 1990 to 1998.

To measure the degree of fractionalization in a party system I employ the commonly used Rae's Index of Fractionalization (Rae 1967). The measure is calculated based upon the share of seats each party receives and is based upon the following formula:

$$
\text { FRACTION }=1-\Sigma p_{i}^{2}
$$

where $p_{i}=$ fractional share of the I-th component (meaning the seat shares for each party) and $\Sigma=$ the summation overall squared components. The value ranges from 0 to 1 . If all the components have extremely small seat shares the FRACTION tends toward 1; at the other extreme, if one party receives all of the seats then the value tends toward 0 .

\section{Organizational Institutionalization}

Based upon both Janda and Huntington, I employ four measures of institutionalization: Name Changes prior to 1989, Average Leadership Duration in Old Party, Degree of Organization, and Occurrence of 
Organizational Splits Prior to 1989. As Janda notes, party name changes are often made to establish new links with the electorate, as well resulting in confusion about the party's identity within the citizenry as a whole. Thus the magnitude and frequency of name changes relates to the degree of institutionalization of the party organization; the greater the frequency and magnitude of changes indicates less institutionalization.

In keeping with Janda's measure, the magnitude of name changes was assessed in terms of minor and major changes. A minor change was defined as one that involves the repetition of one or more terms (not including prepositions) in both the previous name and the changed name. A complete change involved the repetition of no terms. The measure of magnitude was combined with the frequency of name changes to produce the measure Name changes prior to 1989. This variable was coded as an ordinal measure ranging from 0 to three where 0 indicated "no name changes," 1 indicated "one minor change," 2 indicated "two or more minor changes or one complete change," and 3 indicated "more than one compete change, including one minor and one complete" (Janda 1980, 22).

Another measure of institutionalization that relates to both Janda and Huntington is the "generational age" of the party organization. This measure assumes that the lack of leadership change leads a party to become closely identified with an individual leader and heightens the propensity for the development of a "cult of personality." Thus, the fewer the number of leadership changes the less adaptable and hence less institutionalized the party is as an organization. To measure generational change, I first determined the number of different chief executive officers the party had up until 1989 (in most cases this was the General or First Secretary, although occasionally it was the party Chairman) and then divided this number by the number of years the party was in existence (dating to its founding). The resulting number measures the average leadership duration in the communist party; the higher the number the longer the tenure of the party leader, and hence the less likely the party was "institutionalized."

An additional measure of the degree to which a party organization is institutionalized relates to the complexity of the organization. As Harmel and Svasand argue (1993) the more organizationally complex the political party the more institutionalized it is. To measure the degree to which a party organization is complex, I borrow from Janda (1980) who noted that organizational complexity involves two dimensions: intensiveness and extensiveness. Intensiveness refers to the smallest unit in the party structure, while extensiveness denotes the geographical coverage of the party organization (Janda 1980, 101).

To measure intensiveness, I employ a modification of Janda's measure that has six discrete categories and ranges from "no observable organiza- 
tion" on one extreme and "cell units" on the other. As Duverger (1964) noted the smallest organizational unit in the party is indicative of the type of party. For instance if the cell is the basis of organization this indicates a profound change in the very concept of the political party. Instead of a body intended for the winning of votes "the political party becomes an instrument of agitation" (Duverger 1964, 35).

To measure intensiveness I reconfigured Janda's measure into four categories where 1 is coded for organizations which either have no institutionalized organs or are only apparent at the national level. The value 2 is assigned to where no institutionalized party organs exist below constituency or municipal level. The value 3 is associated with party organs existing in geographic locations at the precinct level. The value 4 is reserved for party organizations which exist at the cell level (usually involving units of less than 100 party members). ${ }^{3}$

The second dimension indicative of the complexity of the organization (which Janda labeled the degree of organization) is the extensiveness of the party organization. Janda conceived of this as involving the geographic coverage of the party, which was determined by whether the party maintained local organizations throughout the country. This measure, however, proved problematic in application to the communist parties. Many of these parties (particularly in the developing world) were clandestine organizations (even those which were officially legal); hence information on the internal organizational structure of these parties was extremely limited. Thus, rather than employ Janda's measure of extensiveness, I employ a measure of membership density as a surrogate measure. ${ }^{4}$ The assumption here is that the larger the estimated membership the more likely the organization has the wherewithal to maintain local organizations throughout the country. This involves dividing the estimated party membership in 1989 by the population of the country and multiplying by 100 .

To calculate a composite measure of organizational complexity, I multiply the intensiveness score by the membership density score and divide the product by 100 to render a value which estimates the degree of organization of the communist party before the collapse of communism in 1989 .

Finally, I consider the extent to which the previous communist party organization was "coherent" defined in terms of basic consensus among the leadership of the party (Huntington 1965, 403-405; Janda 1980, 118). As a basic measure of leadership coherence, I employ a simple dichotomous measure which scores as 1 the situation where the party experiences a major factional struggle which resulted in an organizational split in the party (and the foundation of an alternative party organization) between 1969 (which marked the height of the Sino-Soviet split) to 1989. No split was coded as 0 as was the situation when factionalism did not result in an organizational 
split. The reason for coding the latter as 0 was that even under conditions of rampant factionalism, as long as the party remained organizationally whole, then it was reasonable to assume that there was some basic consensus among the party leadership which held the party leaders together.

\section{Analysis}

Table 1 deals with the factors that affect the probability that the successor party would change its name following the collapse of communism. Two models are reported. The first model (Model 1) includes variables which relate to the external political environment (Challenger Success and Party System Fractionalization) and internal to the party organization (Degree of Organization and Name Changes Prior to 1989). The table reports the results of the logistic regression procedure, regressing the environmental political variables against the dichotomous dependent variable of whether or the successor party changed its name. ${ }^{5}$ In addition to reporting coefficients and goodness of fit measures, the tables also report the results of several collinearity diagnostic tests. Dummy variables are included to test if there are any significant differences between the successor parties in post-communist countries and the remainder of the sample (reported in Model 1) and the successor parties in developed countries and the rest of the sample (reported in Model 2).

As indicated in Model 1, the two environmental variables had little to do whether or not the party changed its name. Further, the coefficients associated with Average Challenger Success and Party System Fractionalization suggests that the greater the challengers' electoral success the more likely the party would change its name, a finding that contradicts some of the literature (e.g., Gregg 1971) which holds that external challenges would make the party less likely to change its name. However, these results $d o$ not necessarily support the arguments made by Janda and others that challenges make it more likely the party will change its identity, given that these relationships are not statistically significant. The one significant relationship is between the composite measure of organizational complexity (Degree of Organization) and the likelihood the party changed its name. However, contrary to the literature that suggested that parties with more mass-like characteristics were less likely to change their names, the sign of the coefficients associated with the organizational complexity is positive, indicating that the more organizationally complex the party the more likely that party changed its name.

Although this finding is contrary to some literature, it supports the notion that communist successor parties that emerged from organizationally complex parties are more willing to adapt to new political circumstances 
Table 1. Coefficient Estimates and Collinearity Diagnostics, Logistic Regression for Communist Successor Party Name Change

\begin{tabular}{lcc}
\hline Variable & Model 1 & Model 2 \\
\hline Challenger Success & .01 & -.01 \\
Party System Fractionalization & -.47 & -.27 \\
Degree of Organization & $1.88^{* *}$ & $3.34^{* * *}$ \\
Name Changes Prior to 1989 & .08 & .05 \\
Dummy Variable for & & \\
Post-Communist Countries & .61 & \\
Dummy Variable for & & .27 \\
Developed Countries & & 79 \\
N $=$ & 79 & $48.28^{* * *}$ \\
Model Chi-square & $50.38^{* * *}$ & 75.18 \\
Percent Correctly Predicted & 85.17 & \\
${ }^{*} \mathrm{p} \leq .10 ; *$ p $\leq .05 ; * * \mathrm{p} \leq 01$. & & \\
\hline
\end{tabular}

than are parties which are not organizationally complex (Huntington 1965; Harmel and Janda 1994). Importantly, as indicated in Table 1, whether or not the party changed its name was unrelated to whether or not the communist successor party was from the post-communist countries. Table 1 results indicate that whether or not the party changed its name was unrelated to whether or not the party was from a developed country. Thus, these relationships are not a function of whether the successor parties were from postcommunist countries, developed countries or developing countries.

Table 2 examines another aspect of party identity change, in this case whether or not the successor party explicitly rejected Marxism-Leninism. Unlike in Table 1 the measure of organizational complexity had little to do with whether or not the successor party explicitly rejected Marxism-Leninism (although the sign of the coefficient would suggest that more organizationally complex parties were more likely to reject Marxism-Leninism). In both tables none of the independent variables exhibit a statistically significant relationship with whether or not the party rejected Marxism-Leninism. Interestingly, the degree to which the party system was fractionalized was unrelated to whether or not the party rejected Marxism. This contradicts the notion that competition drives ideological change contrary to the argument put forward by Harmel and Janda. Again, as with the results reported in Table 2, whether or not the party rejected Marxism-Leninism was unrelated 
Table 2. Coefficient Estimates and Collinearity Diagnostics, Logistic Regression for Communist Successor Party Position Regarding Marxism-Leninism

\begin{tabular}{lcc}
\hline Variable & Model 3 & Model 4 \\
\hline Challenger Success & .00 & .00 \\
Party System Fractionalization & -.64 & -.64 \\
Degree of Organization & .69 & .32 \\
Name Changes Prior to 1989 & .05 & .04 \\
Dummy Variable for & & \\
Post-Communist Countries & -20 & \\
Dummy Variable for & & .08 \\
Developed Countries & & 79 \\
$\mathrm{~N}=$ & 79 & 5.60 \\
Model Chi-square & 6.60 & 58.11 \\
Percent Correctly Predicted & 68.12 & \\
$* \mathrm{p} \leq .10 ; * * \mathrm{p} \leq .05 ; * * \mathrm{p} \leq 01$. & & \\
\hline
\end{tabular}

to whether or not the party was from a post-communist country or a developed country. Thus, these relationships are not a function of whether the successor parties were from post-communist countries, developed countries or developing countries.

Tables 3 and 4 report the effect changing the party's identity had on its electoral performance. In Table 3 the variables name change prior to the first election and whether or not the party had rejected Marxism-Leninism prior to the first election are combined into a single measure of party identity change, which is comprised of three categories - "no change" (where neither name was changed nor did the party reject Marxism-Leninism) "partial change" (where the party either changed its name or rejected MarxismLeninism) and "complete change" (where the party both changed its name and rejected Marxism-Leninism). The resulting variable is then cross tabulated with the degree of electoral success the party enjoyed in the first legislative election. As Table 5 indicates, there is a statistically significant $(\mathrm{p}=.00)$ and fairly strong relationship $($ gamma $=.56)$ between the degree of party identity change and performance in the first legislative election. Thirteen of the 21 parties $(62 \%)$ that changed their identity prior to the first election won at least five percent of the legislative seats. ${ }^{5}$ The 13 parties that both changed their names and rejected Marxism-Leninism officially and 


\section{Table 3. Crosstabulation, Electoral Performance in First Election by Whether the Party Had Changed Name and/or Rejected Marxism-Leninism}

\begin{tabular}{|c|c|c|c|c|}
\hline & $\begin{array}{l}\text { Had not rejected } \\
\text { Marxism-Leninism } \\
\text { and had not } \\
\text { changed name prior } \\
\text { to first election } \\
\text { (column percent) }\end{array}$ & $\begin{array}{l}\text { Had rejected } \\
\text { Marxism-Leninism } \\
\text { and had not changed } \\
\text { name / Had not } \\
\text { rejected Marxism- } \\
\text { Leninism and had } \\
\text { changed name prior } \\
\text { to first election }\end{array}$ & $\begin{array}{l}\text { Had rejected } \\
\text { Marxism-Leninism } \\
\text { and had changed } \\
\text { name prior to } \\
\text { first election } \\
\text { (column percent) }\end{array}$ & $\begin{array}{l}\text { Row } \\
\text { Total }\end{array}$ \\
\hline $\begin{array}{l}\text { Won } \\
\text { no seats }\end{array}$ & $\begin{array}{c}17 \\
(70.8)\end{array}$ & $\begin{array}{c}12 \\
(36.4)\end{array}$ & $\begin{array}{c}5 \\
(23.8)\end{array}$ & 34 \\
\hline $\begin{array}{l}\text { Won from } .01 \\
\text { to } 4.99 \%\end{array}$ & $\begin{array}{c}4 \\
(16.7)\end{array}$ & $\begin{array}{c}9 \\
(27.3)\end{array}$ & $\begin{array}{c}3 \\
(14.3)\end{array}$ & 16 \\
\hline $\begin{array}{l}\text { Won } 5 \% \\
\text { or more }\end{array}$ & $\begin{array}{c}3 \\
(12.5)\end{array}$ & $\begin{array}{c}12 \\
(36.4)\end{array}$ & $\begin{array}{c}13 \\
(61.9)\end{array}$ & 28 \\
\hline Column Total & 24 & 33 & 21 & 78 \\
\hline \multicolumn{5}{|c|}{$\begin{array}{l}\mathrm{N}=78 \\
\text { Pearson Chi-square }=15.29 \\
\text { Gamma }=.56 \\
\text { Significance }=.00\end{array}$} \\
\hline
\end{tabular}

won at least five percent of the legislative seats were Western or postcommunist parties. They included Bulgaria, Croatia, Finland, Hungary, Italy, Lithuania, Macedonia, Poland, Romania, San Marino, Slovakia, and Yugoslavia.

Only five parties that changed their names prior to the first election after the collapse of communism did not win seats in the legislature. These included not only three parties from "developed countries" (Great Britain, Belgium and Australia), but also from the post-communist countries of Slovenia and Estonia. By contrast, overall 71 percent (17 of 24) of the parties that had not changed their identity prior to the first legislative election won no seats in the first legislative elections. Of these parties, twelve were from western or post-communist countries, including Armenia, Austria, Canada, Denmark, Ireland, Luxembourg, Malta, Mongolia, New Zealand, Norway, Portugal, and the United States. In other words, even when comparing only Western and post-communist cases, communist successor parties that changed their identity prior to the first elections performed better than parties that either did not change their identities or only changed after the first elections. 
Table 4. Crosstabulation, Change in Electoral Performance from First to Second Elections by Whether the Party Had Changed Name and/or Rejected Marxism-Leninism

\begin{tabular}{|c|c|c|c|c|}
\hline & $\begin{array}{l}\text { Had not rejected } \\
\text { Marxism-Leninism } \\
\text { and had not } \\
\text { changed name prior } \\
\text { to first election } \\
\text { (column percent) }\end{array}$ & $\begin{array}{c}\text { Had rejected } \\
\text { Marxism-Leninism } \\
\text { and had not changed } \\
\text { name / Had not } \\
\text { rejected Marxism- } \\
\text { Leninism and had } \\
\text { changed name prior } \\
\text { to first election }\end{array}$ & $\begin{array}{l}\text { Had rejected } \\
\text { Marxism-Leninism } \\
\text { and had changed } \\
\text { name prior to } \\
\text { first election } \\
\text { (column percent) }\end{array}$ & $\begin{array}{l}\text { Row } \\
\text { Total }\end{array}$ \\
\hline $\begin{array}{l}\text { No change or } \\
\text { lost seats from } \\
\text { first to second } \\
\text { election }\end{array}$ & $\begin{array}{c}17 \\
(89.5)\end{array}$ & $\begin{array}{c}17 \\
(56.6)\end{array}$ & $\begin{array}{c}10 \\
(50.0)\end{array}$ & 44 \\
\hline $\begin{array}{l}\text { Increased shar } \\
\text { of seats from } \\
\text { first to second } \\
\text { election }\end{array}$ & $\begin{array}{c}2 \\
(10.5)\end{array}$ & $\begin{array}{c}12 \\
(41.4)\end{array}$ & $\begin{array}{c}10 \\
(50.0)\end{array}$ & 24 \\
\hline $\begin{array}{l}\text { Column Total } \\
\mathrm{N}=78 \\
\text { Pearson Chi-squ } \\
\text { Gamma }=.52 \\
\text { Significance }=. \\
\text { *Eleven countri }\end{array}$ & $\begin{array}{l}19 \\
\text { dare }=7.47 \\
02 \\
\text { es had yet to have had se }\end{array}$ & ond free election by 199 & 20 & $68^{*}$ \\
\hline
\end{tabular}

What is more important than initial electoral performance is whether changing identities was associated with improved electoral performance. Table 4 reports the relationship between early party identity change and change in performance from the first to the second legislative election for 68 of the 79 parties (11 countries had not yet had their second free election by October 1998). This allows for assessment of the longer-term effects of party identity change on electoral performance. In Table 4 the dependent variable is reconfigured into two categories. The first includes either the situation where the party lost seats in the second election or there was no change. The second includes parties that experienced an increase in its share of legislative seats when comparing the first and second elections. Again there appears to be a relationship between the degree of party identity change and the party's electoral success over time $(p=.02)$, and this relationship is fairly strong (gamma $=.52$ ). The ten countries that changed names and identities, and had improved electoral performance, included Bulgaria, Croatia, Finland, Germany, Hungary, Italy, Macedonia, Nether- 
lands, Sweden and Yugoslavia. Early change in a successor party's identity thus translates into improved electoral performance over time.

As with Table 3, these cases also ranked high in terms of the degree of organization. This finding is consistent with the findings in Table 1 -the greater the degree of organization, the more likely the party would change its identity, and the more likely those changes led to dividends in terms of improved electoral performance later.

\section{Discussion}

The most important factor explaining the electoral success of the communist successor parties is the degree of organization. This finding provides broader support for the literature based on the Eastern European and FSU cases that argues that communist successor party electoral performance is primarily a result of the organizational features the parties inherited from the past (Ishiyama 1997). Further, the degree of organization was related to the adaptability of the successor party, which lend support to the notion that adaptable parties are those which are organizationally complex. In turn this adaptability paid dividends for the successor parties. More adaptable parties have been far more electorally successful than less adaptable parties, and the key to adaptability lies in the party organization's internal features.

The development of the communist successor parties across has important ramifications for the furtherance of democratic consolidation of new democracies. Although not all of the communist successor parties have promoted democratic consolidation, at least some have assisted democratic development by promoting the acceptance of democracy among their supporters in occupational groups most hurt by the political and economic transition. However, the extent to which the successor parties play this role may depend much less on the political environment, but much more on organizational kinds of parties they become.

\section{APPENDIX \\ Communist Parties and Their Successors}

\begin{tabular}{lll}
\hline Country & Communist Party & Successor Party \\
\hline Albania & Albanian Party of Labor & Socialist Party of Albania \\
Argentina & Communist Party of Argentina & United Left \\
Armenia & Communist Party of Armenia & Armenian Communist Party \\
Australia & Communist Party of Australia & New Left Party \\
Austria & Communist Party of Austria & Communist Party of Austria \\
Azerbaijan & Communist Party of Azerbaijan & Azerbaijan United \\
& & Communist Party
\end{tabular}


Appendix (continued)

\begin{tabular}{|c|c|c|}
\hline Country & Communist Party & Successor Party \\
\hline Bahamas & Vanguard Socialist Party & Vanguard Socialist Party \\
\hline Bangladesh & Communist Party of Bangladesh & Communist Party of Bangladesh \\
\hline Belarus & Communist Party of Belarus & Communist Party of Belarus \\
\hline Belgium & Belgian Communist Party & Belgian Communist Union \\
\hline Benin & $\begin{array}{l}\text { People's Revolutionary Party } \\
\text { of Benin }\end{array}$ & None \\
\hline Bolivia & Communist Party of Bolivia & Communist Party of Bolivia \\
\hline Brazil & Brazilian Communist Party & Popular Socialist Party \\
\hline Bulgaria & Bulgarian Communist Party & Bulgarian Socialist Party \\
\hline Canada & Communist Party of Canada & Communist Party of Canada \\
\hline Chile & Communist Party of Chile & Communist Party of Chile \\
\hline Columbia & Communist Party of Columbia & Communist Party of Columbia \\
\hline Congo & Congolese Party of labor & Congolese Party of Labour \\
\hline Costa Rica & Popular Vanguard Party & Popular Vanguard Party \\
\hline Croatia & $\begin{array}{l}\text { League of Communists } \\
\text { of Croatia }\end{array}$ & $\begin{array}{l}\text { Social Democratic Party of Croatia- } \\
\text { Party of Democratic Reform }\end{array}$ \\
\hline Cyprus & $\begin{array}{l}\text { Progressive Party of the } \\
\text { Working People }\end{array}$ & $\begin{array}{l}\text { Progressive Party of the } \\
\text { Working People }\end{array}$ \\
\hline Czech Republic & $\begin{array}{l}\text { Communist Party of } \\
\text { Czechoslovakia }\end{array}$ & $\begin{array}{l}\text { Communist Party of Bohemia } \\
\text { and Moravia }\end{array}$ \\
\hline Denmark & Communist Party of Denmark & Communist Party of Denmark \\
\hline Dominican Republic & Dominican Communist Party & Dominican Communist Party \\
\hline Ecuador & Communist Party of Ecuador & Communist Party of Ecuador \\
\hline El Salvador & Communist Party of El Salvador & $\begin{array}{l}\text { Merged into Farabundo Marti } \\
\text { Movement for National } \\
\text { Liberation (1997) }\end{array}$ \\
\hline Estonia & Communist Party of Estonia & Estonian Democratic Labor Party \\
\hline Finland & Communist Party of Finland & Left Wing Alliance \\
\hline France & French Communist Party & French Communist Party \\
\hline Georgia & Georgian Communist Party & $\begin{array}{l}\text { United Communist Party } \\
\text { of Georgia }\end{array}$ \\
\hline Germany & Socialist Unity Party & Party or Democratic Socialism \\
\hline Great Britain & Communist Party of Great Britain & Democratic Left \\
\hline Greece & Communist Party of Greece & Communist Party of Greece \\
\hline Grenada & $\begin{array}{l}\text { Maurice Bishop Patriotic } \\
\text { Movement }\end{array}$ & $\begin{array}{l}\text { Maurice Bishop Patriotic } \\
\text { Movement }\end{array}$ \\
\hline Guyana & Peoples' Progressive Party & Peoples' Progressive Party \\
\hline Honduras & Communist Party of Honduras & Communist Party of Honduras \\
\hline Hungary & Hungarian Socialist Workers Party & Hungarian Socialist Party \\
\hline Iceland & People's Alliance & People's Alliance \\
\hline India & Communist Party of India & Communist Party of India \\
\hline Ireland & Communist Party of Ireland & Communist Party of Ireland \\
\hline Israel & Communist Party of Israel & Communist Party of Israel \\
\hline Italy & Italian Communist Party & Democratic Party of the Left \\
\hline Jamaica & Workers' Party of Jamaica & Workers' Party of Jamaica \\
\hline Japan & Japanese Communist Party & Japan Communist Party \\
\hline Jordan & Communist Party of Jordan & Communist Party of Jordan \\
\hline
\end{tabular}


Appendix (continued)

\begin{tabular}{|c|c|c|}
\hline Country & Communist Party & Successor Party \\
\hline Latvia & Communist Party of Latvia & Latvian Socialist Party \\
\hline Lithuania & Communist Party of Lithuania & $\begin{array}{l}\text { Lithuanian Democratic } \\
\text { Labor Party }\end{array}$ \\
\hline Luxembourg & Communist Party of Luxembourg & Communist Party of Luxembourg \\
\hline Macedonia & $\begin{array}{l}\text { League of Communists } \\
\text { of Macedonia }\end{array}$ & $\begin{array}{l}\text { Social Democratic Union } \\
\text { of Macedonia }\end{array}$ \\
\hline Malta & Communist Party of Malta & Communist Party of Malta \\
\hline Mexico & Mexican Socialist Party & $\begin{array}{l}\text { Party of the Democratic } \\
\text { Revolution }\end{array}$ \\
\hline Moldova & Communist Party of Moldova & $\begin{array}{l}\text { Socialist Party of Moldova and } \\
\text { Party of Moldovan Communists }\end{array}$ \\
\hline Mongolia & $\begin{array}{l}\text { Mongolian People's } \\
\text { Revolutionary Party }\end{array}$ & $\begin{array}{l}\text { Mongolian People's } \\
\text { Revolutionary Party }\end{array}$ \\
\hline Morocco & Party of Renewal and Progress & Party of Renewal and Progress \\
\hline Nepal & Nepal Communist Party & United Communist Party of Nepal \\
\hline Netherlands & Communist Party of the Netherlands & Green Left \\
\hline New Zealand & Communist Party of New Zealand & Socialist Workers' Organization \\
\hline Nicaragua & Nicaraguan Socialist Party & Nicaraguan Socialist Party \\
\hline Norway & Norwegian Communist Party & Norwegian Communist Party \\
\hline Panama & People's Party & People's Party \\
\hline Paraguay & Paraguayan Communist Party & Paraguayan Communist Party \\
\hline Philippines & Philippine Communist Party & Philippine Communist Party \\
\hline Poland & Polish Socialist Workers Party & $\begin{array}{l}\text { Social Democracy of the } \\
\text { Polish Republic }\end{array}$ \\
\hline Portugal & Portuguese Communist Party & Portuguese Communist Party \\
\hline Romania & Romanian Communist Party & $\begin{array}{l}\text { Party of Social Democracy } \\
\text { of Romania }\end{array}$ \\
\hline Russia & $\begin{array}{l}\text { Communist Party of the } \\
\text { Soviet Union }\end{array}$ & $\begin{array}{l}\text { Communist Party of the } \\
\text { Russian Federation }\end{array}$ \\
\hline San Marino & Communist Party of San Marino & Progressive Democratic Party \\
\hline Senegal & Independence and Labor Party & Independence and Labour Party \\
\hline Slovakia & $\begin{array}{l}\text { Communist Party of Czechoslovakia/ } \\
\text { Communist Party of Slovakia }\end{array}$ & Party of the Democratic Left \\
\hline Slovenia & League of Communist of Slovenia & Party of Democratic Reform \\
\hline South Africa & South African Communist Party & South African Communist Party \\
\hline Spain & Spanish Communist party & Spanish Communist Party \\
\hline Sweden & Left Party Communists & Left Party \\
\hline Switzerland & Swiss Labor Party & Swiss Labor Party \\
\hline Ukraine & Communist Party of Ukraine & Communist Party of Ukraine \\
\hline United States & CPUSA & CPUSA \\
\hline Uruguay & Communist Party of Uruguay & Communist Party of Uruguay \\
\hline Venezuela & Communist Party or Venezuela & Communist Party of Venezuela \\
\hline Yugoslavia & League of Communists & $\begin{array}{l}\text { Socialist Party of Serbia/ } \\
\text { Democratic Party of Socialists } \\
\text { of Montenegro }\end{array}$ \\
\hline
\end{tabular}




\section{NOTES}

${ }^{1}$ In all cases in this research, if a party claimed to be the legal successor then it was labeled the successor party. If there were two legal successors, then we judged which of the parties received the bulk of the organizational resources and personnel. Thus we could distinguish between the Hungarian Socialist Party and the Hungarian Socialist Workers' Party, or the KPRF and other minor communist formations in Russia - such as Viktor Anpilov's Working Russia Blok.

${ }^{2}$ In two cases two successor parties were identified. For instance in Moldova the Socialist Party/Yedinstvo was the primary successor party in 1992. This party was primarily made up of ethnic Russians. However by the time of the 1998 election another successor party emerged among Romanian speakers, the Party of Moldovan Communists which absorbed a large chunk of the membership and resources of the Socialist Party. In the case of rump Yugoslavia, the Socialist Party of Serbia and the Democratic Party of Socialists of Montenegro ran separately for the Federal Assembly. In both these cases, the seat share of the two parties was combined as an indicator of communist successor party electoral performance.

${ }^{3}$ The data for this measure came from the in depth descriptions of parties available in the Yearbook of International Communist Affairs (YICA), 1966-1991.

${ }^{4}$ Membership density data for the parties was derived from the Yearbook of International Communist Affairs, 1966-1991. The coding of the extensiveness variable was derived from this source as well which has descriptions of party organizational structure.

${ }^{5}$ I use the cutoff of five percent because in most legislative elections (particular proportional representation systems) a five percent electoral threshold is used in order to award seats.

\section{REFERENCES}

Agh, Attila. 1995. Partial Consolidation of the East-Central European Parties: The Case of the Hungarian Socialist Party. Party Politics 1:491-514.

Bell, David S., ed. 1993. Western European Communists and the Collapse of Communism. London: Berg Publishers.

Bozoki, Andras. 1997. The Ideology of Modernization and the Policy of Materialism: The Day After for the Socialists. Journal of Communist Studies and Transition Politics 13:56-102.

Breuning, Marijke and John T. Ishiyama. 1998. The Rhetoric of Nationalism: Rhetorical Strategies of the Volksunie and Vlaams Blok in Belgium, 1991-1995. Political Communication 15:5-26.

Budge, Ian, David Robertson, and Derek Hearl, eds. 1987. Ideology, Strategy and Party Change: Spatial Analysis of Post-War Election Programmes in Nineteen Democracies. Cambridge: Cambridge University Press.

Duverger, Maurice. 1964. Political Parties. London: Methuen.

Epstein, Leon D. 1967. Political Parties in Western Democracies. New York: Praeger.

Evans, Geoffrey, and Stephen Whitefield. 1995. Economic Ideology and Political Success: Communist-Successor Parties in the Czech Republic, Slovakia and Hungary Compared. Party Politics 1:565-578.

Fox, John. 1991. Regression Diagnostics. Newbury Park, CA: SAGE. 
Gregg, Richard B. 1971. The Ego-Function of the Rhetoric of Protest. Philosophy and Rhetoric 4:72-82.

Grzymala-Busse, Anna. 1999. Czech and Slovak Communist Successor Party Transformations after 1989: Organizational Resources, Elite Capacities and Public Commitments. In Communist Successor Parties in Post-Communist Politics, ed. John Ishiyama. Carmack, NY: Nova Science.

Harmel, Robert, and Lars Svasand. 1993. Party Leadership and Party Institutionalisation: Three Phases of Development. West European Politics 16:67-88.

Harmel, Robert, and Kenneth Janda. 1994. An Integrated Theory of Party Goals and Party Change. Journal of Theoretical Politics 6:259-287.

Huntington, Samuel. 1965. Political Development and Political Decay. World Politics 17: 386-430.

Ishiyama, John. 1995. Communist Parties in Transition: Structures, Leaders and Processes of Democratization in Eastern Europe. Comparative Politics 27:146-177.

Ishiyama, John. 1996. Red Phoenix? The Communist Party in Post-Soviet Russian Politics. Party Politics 2:147-175.

Ishiyama, John. 1997. The Sickle or the Rose? Previous Regime Types and the Evolution of the Ex-Communist Parties in Post-Communist Politics. Comparative Political Studies 30:258-274.

Ishiyama, John. 1998. Red Versus Expert: Candidate Recruitment and Communist Party Adaptation in Post Soviet Politics. Party Politics 4:297-318.

Ishiyama, John, and Matthew Velten. 1998. Presidential Power and Democratic Development in Post-communist Politics. Communist and Post-Communist Studies 31:217234.

Janda, Kenneth. 1980. Political Parties: A Cross-National Survey. New York: Free Press.

Janda, Kenneth. 1990. Toward a Performance Theory of Change in Political Parties. Paper presented at the 12th World Congress of the International Sociological Association, Madrid, Spain.

Janda, Kenneth, Robert Harmel, Christine Edens, and Patricia Goff. 1995. Changes in Party Identity: Evidence from Party Manifestos. Party Politics 1:171-196.

Kitschelt, Herbert. 1995. Formation of Party Cleavages in Post-Communist Democracies: Theoretical Propositions. Party Politics 1:447-472.

Kopecky, Petr. 1995. Developing Party Organizations in East-Central Europe: What Type of Party is Likely to Emerge? Party Politics 1:515-544.

Mahr, Allison, and John Nagle. 1995. Resurrection of the Successor Parties and Democratization in East-Central Europe. Communist and Post-Communist Studies 28:393409.

Oltay, Edith. 1994. Hungarian Socialists Prepare for Comeback. RFE/RL Research Report 3(12):21-26.

Orenstein, Mitchell. 1998. A Genealogy of Communist Successor Parties in East-Central Europe and the Determinants of their Success. East European Politics and Societies 12:472-499.

Panebianco, Angelo. 1988. Political Parties: Organization and Power. Cambridge: Cambridge University Press.

Racz, Barnabas. 1993. The Socialist Left Opposition in Post-communist Hungary. Europe-Asia Studies 45:647-670.

Rae, Douglas. 1967. The Political Consequences of Electoral Laws. New Haven, CT: Yale University Press.

Roskin, Michael. 1993. The Emerging Party Systems of Central and Eastern Europe. East European Quarterly 27:50-62. 
Schlesinger, Joseph. 1984. On the Theory of Party Organization. Journal of Politics 46: 369-400.

Stewart, Charles J. 1991. The Internal Rhetoric of the Knights of Labor. Communication Studies 42:67-82.

Taagepera, Rein, and Matthew Shugart. 1989. Seats and Votes: The Effects and Determinants of Electoral Systems. New Haven, CT: Yale University Press.

Tarrow, Sidney. 1989. Struggle, Politics and Reform: Collective Action, Social Movements and Cycles of Protest. Ithaca, NY: Cornell University, Western Societies Papers.

Urban, Joan Barth, and Vladimir Solovei. 1997. Russia's Communists at the Crossroads. Boulder, CO: Westview Press.

Waller, Michael. 1995. Adaptation of the Former Communist Parties of East Central Europe: A Case of Democratization? Party Politics 1: 373-390.

Weinberg, Leonard. 1995. The Transformation of Italian Communism. New York: Transaction Publishers.

Welsh, Helga. 1994. Political Transition Processes in Central and Eastern Europe. Comparative Politics 26:379-391.

YICA. 1966-1991. Yearbook of International Communist Affairs. Stanford: Hoover Institution Press.

Young, Lisa. 1996. Women's Movements and Political Parties: A Canadian-American Comparison. Party Politics 2:229-250.

Ziblatt, Daniel F. 1998. The Adaptation of Ex-Communist Parties to Post-Communist East Central Europe: A Comparative Study of the East German and Hungarian ExCommunist Parties. Communist and Post Communist Studies 31:119-137. 